\title{
Comparative study of the clinical profile of chronic dacryocystitis and chronic rhinosinusitis after external dacryocystorhinostomy
}

This article was published in the following Dove Press journal: Clinical Ophthalmology

\author{
Luciana MC Soriano' \\ Nadyr A Damasceno ${ }^{1,2}$ \\ Guilherme Herzog Neto' \\ Eduardo F Damasceno' \\ 'Department of Ophthalmology, \\ Universidade Federal Fluminense, \\ Niterói, Brazil; ' ${ }^{2}$ Department of \\ Ophthalmology, Hospital Naval Marcílio \\ Dias, Rio de Janeiro, Brazil
}

Purpose: To compare the clinical profile of patients with chronic dacryocystitis (CDC) with and without associated chronic rhinosinusopathies who had been submitted to external dacryocystorhinostomy (EDCR).

Methods: This was a retrospective, observational, and longitudinal study that included all patients diagnosed with CDC who were submitted to EDCR at the Antonio Pedro University Hospital. Patients were divided into two groups, with and without rhinosinusopathies (Group I and Group II, respectively). The following variables were assessed to compare the Group I and Group II: age, ethnicity, epiphora, discharge by expression of the lacrimal sac, duration of the CDC, and previous history of CDC exacerbation.

Results: The study included a total of 78 patients, 22 patients $(28.2 \%)$ in Group I and 56 patients $(71.8 \%)$ in Group II. The mean age was $64.3( \pm 19.7)$ years. In Group I and II predominated elderly, female, and White $(p=0.93, p=0.38, p=0.77)$. In relation to the clinical characteristics, most of the patients presented epiphora and discharge by compression of the lacrimal sac in both Groups $(p=0.61, p=0.44)$. In relation to a previous history of exacerbations of the CDC, six patients in Group I and four patients in Group II presented it as purulent discharge $(p=0.04)$.

Conclusion: Chronic rhinosinusopathies may favor episodes of exacerbations of chronic dacryocystitis in particular with the presence of purulent discharge.

Keywords: rhinosinusopathies, acquired nasolacrimal duct stenosis, chronic lacrimal fluid retention, acute rhinosinusitis

\section{Introduction}

The nasolacrimal duct obstruction occurs in nearly $5 \%$ of the general population. ${ }^{1}$ Frequently, dacryocystitis (DC) arises from an acquired nasolacrimal duct stenosis, causing an outflow impediment and further infection and inflammation of the pooling tears in the lacrimal sac. ${ }^{2,3}$ The main etiology of DC remains unclear. Albeit, described being as an idiopathic etiology, the primary condition of chronic lachrymal fluid retention, it has been implied as an initial inflammatory process, and secondarily evolve to an ascending inflammation from the nose and sinuses. ${ }^{1,4}$ Approximately $16 \%$ of the adult population has chronic rhinosinusitis which can coexist with the DC whereas the lacrimal drainage system is anatomically linked to the nasal mucosa. ${ }^{5}$

Post-operative acute rhinosinusitis after dacryocystorhinostomy has been reported in just a few studies, with rates of $2 \%$ for acute maxillary sinusitis and $0.3-2 \%$ for frontal sinuses. ${ }^{6,7}$
Correspondence: Eduardo F Damasceno Department of Ophthalmology,

Universidade Federal Fluminense, Rua

Marquês do Paraná 303, Centro, Niterói, Brazil

Tel +55 2l 26202343

Email eduardo_damasceno@id.uff.br 
The current study aims to compare the clinical profile of patients with chronic dacryocystitis (CDC) and patients with associated chronic rhino-sinusopathies who had been submitted to primary external dacryocystorhinostomy (EDCR).

\section{Methods}

The current study is a retrospective, observational, and longitudinal study embracing all patients with primary obstruction of the lower lacrimal drainage system due to iCDC who underwent EDCR by a single surgeon (LMCS) from March 2016 to December 2017, at the Antonio Pedro University Hospital. This study complied with the Guidelines and Norms for Research with Human Beings (National Health Council Resolution 196/1996) and was approved by the Institutional Review Board of the Universidade Federal Fluminense School of Medicine. This study was conducted in accordance with the Declaration of Helsinki. Patients provided written, informed consent.

The inclusion criteria included all patients with primary obstruction of the lower lacrimal drainage system due to CDC who underwent EDCR. Patients were excluded from the study if presented, nose trauma, and other etiologies that could entail secondary CDC (tumors of the lacrimal drainage system, granulomatous diseases as Sarcoidosis and Wegener's Granulomatosis, previous history of radiotherapy of the face and thyroid, and others). CDC was defined clinically as mild inflammation associated with discharge for a period longer than 2 weeks.

The collected data from all patients included personal data (gender, ethnicity, and age), and clinical history, complaints of lacrimal sac inflammation/infection (excessive tearing, pain, epiphora, crusting of the eyelids, abscess of the lacrimal sac, and others), duration of the CDC, previous history of exacerbations, and associated rhinosinusopathies. All patients were followed for 12 months.

In this study, chronic rhinosinusopathies (CRS) were defined as chronicle, allergic, non- infectious, and lasting more than 12 weeks.

Patients were stratified into two categories based on the presence of associated CRS (Group I) or absence of associated CRS (Group II).

Regarding the exams, all patients were subjected to inspection, biomicroscopy, palpation, and digital expression of the lacrimal sac; fluorescein disappearance test; and probing and lacrimal system irrigation. Computed tomography (CT) was performed to rule out extrinsic causes of obstruction of the lacrimal drainage system and also to identify the presence of CRS.

\section{Surgical technique}

The patients were submitted to a standard EDCR under general anesthesia. The medial canthal area was injected subcutaneously with $2 \%$ lidocaine with 1:100,00 epinephrine. The skin was incised, followed by dissection till the periosteum of the frontal process of the maxillary was found. An osteotomy of 1.5-2 and 1.5-2 cm was made, and the lacrimal sac and mucosa were opened to originate anterior and posterior flaps. The wound was closed with 6.0 poliglactina suture. Postoperatively, patients were treated with topical dexamethasone, polymyxin B sulfate, and neomycin sulfate, three times a day for 10 days, and oral amoxicillin and clavulanate $(875 \mathrm{mg})$ twice a day for 5 days.

\section{Investigated variables}

In this study, the Group I and II were compared using the following investigated variables: age, divided into adults (19-59 years) and elderly ( $\geq 60$ years), ethnicity (Latin and white, afro-descendent, and others), epiphora (presence or absence), digital expression of the lacrimal sac (presence or absence of discharge), duration of the CDC, and previous history of $\mathrm{CDC}$ exacerbation (presence or absence).

\section{Statistical analysis}

Statistical analysis was performed employing the software IBM-SPSS, 2015, Chicago, USA, version 23.0 IBM. The level of significance was established as $5 \% \quad(p<0.05)$. Continuous values as age and duration of the CDC (years) were expressed as mean \pm standard deviation (Student's $t$-test). Nominal data (ethnicity, epiphora, gender, age range, digital expression of the lacrimal sac, previous history of CDC exacerbation) were assessed through the Chi-squared test.

\section{Results}

A total of 78 patients were included in this study; two patients were excluded due to sarcoidosis and adenocarcinoma diagnosed by histopathological examination performed with the samples collected during the EDCR. Group I had 22 patients (28.2\%) while Group II had 56 patients (71.8\%). Demographic data are summarized in Table 1. The mean age was $64.3( \pm 19.7)$ years for all patients with CDC submitted to EDCR, 
Table I Demographic data (age, age group, gender, and ethnicity)

\begin{tabular}{|c|c|c|c|c|c|c|c|}
\hline & \multicolumn{6}{|c|}{ Rhinosinusities } & \multirow[t]{3}{*}{$p$-Value } \\
\hline & \multicolumn{2}{|c|}{ Total samples } & \multicolumn{2}{|c|}{ Group I: } & \multicolumn{2}{|c|}{ Group II: } & \\
\hline & n (78) & $\%$ & n (22) & $\%$ & n (56) & $\%$ & \\
\hline $\begin{array}{l}\text { Age - years old } \\
(\text { mean } \pm S D)\end{array}$ & \multicolumn{2}{|c|}{$64.3 \pm 19.7$} & \multicolumn{2}{|c|}{$59.8 \pm 4.4$} & \multicolumn{2}{|c|}{$60.1 \pm 14.7$} & $0.47^{\S}$ \\
\hline \multicolumn{8}{|l|}{ Age group } \\
\hline $\begin{array}{l}19-59 \text { years-old } \\
\geq 60 \text { years-old }\end{array}$ & $\begin{array}{l}20 \\
58\end{array}$ & $\begin{array}{l}25.5 \\
74.3\end{array}$ & $\begin{array}{l}5 \\
17\end{array}$ & $\begin{array}{l}22.7 \\
77.2\end{array}$ & $\begin{array}{l}15 \\
41\end{array}$ & $\begin{array}{l}26.7 \\
73.2\end{array}$ & $0.93^{t}$ \\
\hline \multicolumn{8}{|l|}{ Ethnicity } \\
\hline $\begin{array}{l}\text { Black } \\
\text { White } \\
\text { Other }\end{array}$ & $\begin{array}{l}22 \\
55 \\
1\end{array}$ & $\begin{array}{l}28.2 \\
70.5 \\
1.2\end{array}$ & $\begin{array}{l}6 \\
16 \\
0\end{array}$ & $\begin{array}{l}27.2 \\
72.7 \\
0\end{array}$ & $\begin{array}{l}16 \\
39 \\
1\end{array}$ & $\begin{array}{l}28.5 \\
69.6 \\
1.7\end{array}$ & $0.77^{t}$ \\
\hline \multicolumn{8}{|l|}{ Gender } \\
\hline $\begin{array}{l}\text { Female } \\
\text { Male }\end{array}$ & $\begin{array}{l}50 \\
28\end{array}$ & $\begin{array}{l}64.1 \\
35.8\end{array}$ & $\begin{array}{l}17 \\
5\end{array}$ & $\begin{array}{l}77.2 \\
22.7\end{array}$ & $\begin{array}{l}33 \\
23\end{array}$ & $\begin{array}{l}58.9 \\
41.1\end{array}$ & $0.38^{t}$ \\
\hline
\end{tabular}

Notes: $p$-value - statistical significance, $\S$ - Student $t$-test, $\ell$ - chi-squared statistical test with Yates correction.

Abbreviations: $n$, patient's number; \%, percentage; SD, standard deviation.

$60.1( \pm 14.7)$ years in Group I and $59.8( \pm 4.4)$ years in Group II $(p=0.47)$. The predominant age range in the study was elderly, 58 out of 78 patients $(76.8 \%), 17$ patients in Group I (77.2\%) and 41 patients in Group II (73.2\%) $(p=0.93)$. Regarding the gender, there was a predominance of female with 50 of 78 patients
(64.1\%), 17 patients in Group I $(77.2 \%)$ and 33 patients in Group II (58.9\%). Herein, there was no statistical significance for this variable $(p=0.38)$. This study presented 55 white patients $(70.5 \%), 16$ patients in Group I (72.7\%) and 39 patients in Group II (69.6\%) $(p=0.77)$.

Table 2 Signs, symptoms, and other CDC features

\begin{tabular}{|c|c|c|c|c|c|c|c|}
\hline & \multirow{2}{*}{\multicolumn{2}{|c|}{ Total samples }} & \multicolumn{4}{|c|}{ Rhinosinusities } & \multirow[t]{3}{*}{$p$-Value } \\
\hline & & & \multicolumn{2}{|c|}{ Group I: } & \multicolumn{2}{|c|}{ Group II: } & \\
\hline & n (78) & $\%$ & n (22) & $\%$ & n (56) & $\%$ & \\
\hline \multicolumn{8}{|l|}{ Epiphora } \\
\hline Present & 66 & 84.6 & 20 & 90.9 & 46 & 80.3 & $0.61^{t}$ \\
\hline Absent & 12 & 15.3 & 2 & 9.1 & 10 & 17.8 & \\
\hline \multicolumn{8}{|c|}{ Digital expression of lacrimal sac } \\
\hline Positive & 57 & 73.1 & 17 & 77.2 & 40 & 71.4 & $0.44^{t}$ \\
\hline Negative & 21 & 26.9 & 5 & 22.7 & 16 & 28.5 & \\
\hline \multicolumn{8}{|c|}{ Exacerbation of the CDC } \\
\hline Present & 10 & 12.8 & 6 & 27.2 & 4 & 7.1 & $0.04^{E}$ \\
\hline Absent & 68 & 87.1 & 16 & 72.7 & 52 & 92.8 & \\
\hline \multicolumn{8}{|c|}{ Duration of the CDC } \\
\hline (mean $\pm S D$ in years) & $3.4 \pm 2.1$ & & $3.9 \pm 2.2$ & & $3.5 \pm 1.9$ & & $0.53^{\S}$ \\
\hline
\end{tabular}

Notes: $p$-value - statistical significance, $\S$ - Student $t$ test, $t$ - chi-squared statistical test with Yates correction.

Abbreviations: $\mathrm{n}$, patient's number; \%, percentage; SD, standard deviation. 
In Table 2, the clinical characteristics of $\mathrm{CDC}$ are shown. Epiphora was found in 66 patients (84.6\%), 20 patients in Group I (90.9\%) and 45 patients in Group II $(80.3 \%)$, revealing no statistical significance $(p=0.61)$. Although not statistically significant $(p=0.44)$, the discharge by the digital expression of the lacrimal sac was achieved in 57 patients $(72.9 \%), 17$ patients in Group I (77.2\%) and 40 patients in Group II (71.4\%).

Previous history of exacerbation of CDC identified as purulent discharge, occurred in 10 patients $(12.8 \%), 6$ patients of Group I (27.2\%) and 4 patients of Group II (7.1\%), showing statistical significance $(p=0.04)$.

Previous history of exacerbation of CDC was identified as purulent discharge, occurring in 10 patients (12.8\%), 6 patients of Group I (27.2\%) and 4 patients of Group II (7.1\%), showing statistical significance $(p=0.04)$.

Table 3 summarizes the specific data from the rhinosinusopathies found among the CDC features.

\section{Discussion}

The current study demonstrates the importance of the diagnosis of rhinosinusopathies in patients with CDC since the lacrimal drainage system drains the tear into the nasal cavity.

In a retrospective interventional case series study by Shams and colleagues, 196 patients with symptomatic primary acquired nasolacrimal duct obstruction (PANDO) and common canalicular obstruction who had been submitted to endoscopic dacryocystorhinostomy (EnDCR) was evaluated, resulting in 20 patients $(10.2 \%)$ with the previous history of CRS with no history of acute or CDC. ${ }^{5}$ While the current prospective study comprised only with patients diagnosed with CDC subjected to EDCR. This study compared cases with and without CRS, showing that CRS represented $28.2 \%$ of the patients. Exacerbation of CDC was more frequent among patients with CRS and was the only significative variable. Therefore, the different methodologies employed between the two studies could be one of the possible causes of four studies to present a smaller total sample and a higher percentage of patients with CRS, although the absolute number of patients affected was similar (20-22 patients).

Gudis et al, carried out an updated literature review of cilia dysfunction in CRS which concluded that patients with CRS had a reduction of the mucociliary clearance. ${ }^{8}$ Moreover, other studies have reported this reduction after EDCR and EnDCR. ${ }^{9-11}$

Paulsen and colleagues evaluated the pathophysiology of primary acquired dacryostenosis through the tissue specimens from the human nasolacrimal ducts of 36 patients that underwent EnDCR within a framework of primary acquired dacryostenosis. They said that Inflammation from the eye or the nose leads to swelling of the mucous membrane, rearrangement of the connective tissue fibers, reactive hyperemia from the malfunction of the subepithelial cavernous body, and transitory occlusion of the lacrimal path. Additionaly, repeated isolated DC could originate a total fibrous closure of the lacrimal duct. ${ }^{12}$

The use of CT in patients with symptoms of tearing associated with nasolacrimal duct obstruction (NLDO) was analyzed by Choi and colleagues. The authors found $39(17.8 \%)$ out of 218 patients with both maxillary and ethmoidal sinuses. As most cases of NLDO have unrecognized source, this exam has been suggested by many authors. ${ }^{13-17}$ The present study found 20 of 78 patients with CRS preoperatively by CT. Those outcomes re-emphasize the use of CT to evaluate patients with CDC.

In a case series of 152 patients with NLDO who underwent EDCR, previous episodes of DC were observed in 60 patients (19 males and 41 females) and the mean age was $67 \pm 15$ years. ${ }^{18}$ Lee-Wing et cols found 118 females and 48 males and the mean age was 60.7 years (range, $21-93$ years). ${ }^{19}$ In the present study, the demographic data were not different in patients with and without previous CRS, predominating female patients, elderly, mean age of $64.3 \pm 19.7$ years, and whites. Furthermore, it has been acknowledged that idiopathic

Table 3 Specific rhinosinusopathies and CDC features

\begin{tabular}{|l|l|l|l|l|}
\hline Rhinitis \& rhinosinusitis & $\begin{array}{l}\text { Total } \\
\text { samples }\end{array}$ & Epiphora & $\begin{array}{l}\text { Digital expression of lacrimal } \\
\text { sac }\end{array}$ & $\begin{array}{l}\text { Exacerbation of the } \\
\text { iCDC }\end{array}$ \\
\cline { 2 - 5 } & $\mathbf{n = 2 2}(\%)$ & $\mathbf{n = 2 0}(\%)$ & $\mathbf{n = 1 7}(\%)$ & $\mathbf{n = 6}(\%)$ \\
\hline $\begin{array}{l}\text { Chronic rhinosinusities (involving maxillary sinus) } \\
\text { Chronic rhinitis }\end{array}$ & $\begin{array}{l}14(63.5) \\
8(36.5)\end{array}$ & $\begin{array}{l}13(65) \\
7(35)\end{array}$ & $\begin{array}{l}11(64.7) \\
6(35.3)\end{array}$ & $\begin{array}{l}4(66.7) \\
2(33.3)\end{array}$ \\
\hline
\end{tabular}

Abbreviations: $\mathrm{n}$, patient's number, \%, percentage. 
dacryostenosis is more common in females, mainly after menopause. $^{20-22}$

In conclusion, the physiopathology of CDC is not fully known. This study reveals a possible influence of CRS on the $\mathrm{CDC}$, emphasizing its action on the exacerbation of the symptoms.

\section{Disclosure}

The authors report no conflicts of interest in this work.

\section{References}

1. Traquair HM. Chronic dacryocystitis. Its causation and treatment. Arch Ophthalmol. 1941;26(165):1. doi:10.1001/archopht.1941.00 870140015001

2. Brook I, Frazier EH. Aerobic and anaerobic microbiology of dacryocystitis. Am J Ophthalmol. 1998;125(4):552-554. doi:10.1016/s00029394(99)80198-6

3. Oliver J. Color Atlas of Lacrimal Surgery. Vol. 3. Offord: ButterWorth-Heinemann; 2001:2-23.

4. DeAngelis D, Hurwitz J, Oestreicher J, Howard D. The pathogenesis and treatment of lacrimal obstruction: the value of lacrimal sac and bone analysis. Orbit. 2001;20(3):163-172.

5. Sharma PN, Selva D. Acute post-operative rhinosinusitis following endonasal da. Eye. 2013;27(10):1130-1136. doi:10.1038/eye.2013.147

6. Leong SC, Macewen CJ, White OS. A systematic review of outcomes affter dacryocystorhinostomy in adults. Am J Rhinol Allergy. 2010;24(1):81-90. doi:10.2500/ajra.2010.24.3393

7. Ayet B, Racy E, Assouline M. Complications of standardized endonasal dacryocystorhinostomy with unciformectomy. Ophthalmology. 2004;111(4):837-845. doi:10.1016/j.ophtha.2003.08.023

8. Gudis D, Zhao KQ, Cohen NA. Acquired cilia dysfunction in chronic rhinosinusitis. Am J Rhinol Allergy. 2012;26:1-6. doi:10.2500/ ajra.2012.26.3716

9. Unal M, Oz O, Adiguzel U, Vayisoglu Y, Vatansever H, Gorur K. Mucociliary clearance after external dacryocystorhinosotomy. Clin Otolaryngol Allied Sci. 2004;29:264-265. doi:10.1111/j.13652273.2004.00811.x

10. Yigit O, Kirgezen T, Taskin U, Yener M. Endoscopic dacryocystorhinostomy appears to impair nasal mucociliary clearance. Ear Nose Throat J. 2011;90:E23-E27. doi:10.1177/0145561311090 00921
11. Okuyucu S, Akoglu E, Oksuz H, Gorur N, Dagli S. The effect of dacryocystorhinostomy on mucociliary function. Otolaryngol Head Neck Surg. 2009;140:585-588. doi:10.1016/j.otohns.2008.12.001

12. Paulsen FP, Thale AB, Maune S, Tillmann BN. New insights into the pathophysiology of primary acquired dacryostenosis. Ophthalmology. 2001;108(12):2329-2336. doi:10.1016/S0161-6420(01)00946-0

13. Czyz CN, Bacon TS, Stacey AW, et al. Nasolacrimal system aeration on computed tomographic imaging: se and age variation. Ophtahmic Plast Reconstr Surg. 2016;32(1):11-16. doi:10.1097/ IOP.0000000000000392

14. Czyz CN, Bacon TS, Stacey AW, et al. Nasolacrimal system aeration on computed tomographic imaging: efffects of patient positioning and scan orientation. Clin Ophthalmol. 2015;9:469-473. doi:10.2147/OPTH. S80752

15. Loftus WK, Kew J, Metreweli C. Nasolacrimal duct opacity on CT. Br J Radiol. 1996;69:630-631. doi:10.1259/0007-1285-69-823-630

16. Francis IC, Kappagoda MB, Cole IE, Bank L, Dunn GD. Computed tomography of the lacrimal drainage system: retrospective study of 107 cases of dacryostenosis. Ophthal Plast Reconstr Surg. 1999;15:217-226. doi:10.1097/00002341-199905000-00013

17. Nagi KS, Meyer DR. Utilization patterns for diagnostic imaging in the evaluation off epiphora due to lacrimal obstruction: a national survey. Ophthal Plast Reconstr Surg. 2010;26:168-171. doi:10.1097/ IOP.0b013e3181b8c747

18. Rabina G, Golan S, Neudorfer M, Leibovitch I. External dacryocystorhinostomy: characteristics and surgical outcomes in patients with and without previous dacryocystitis. J Ophthalmol. 2013. doi: $10.1155 / 2013 / 287524$

19. Lee-Wing MW, Ashernhurst ME. Clinicopathologic analysis of 166 patients with primary acquired nasolacrimal duct obstruction. Ophthalmol. 2001;108(11):2038-2040. doi:10.1016/S0161-6420(01) 00783-7

20. Meller J. Diseases of the lacrimal apparatus. Trans Ophthalmol Soc. 1929;49:233-311.

21. Zolli CL, Shannon GM. Dacryocystorhinostomy: a review of 119 cases. Ophthalmic Surg. 1982;13:905-910.

22. Tarbet KJ, Custer PL. External dacryocystorhinostomy. surgical success, patient satisfaction, and economic cost. Ophthalmol. 1995;102:1065-1070.
Clinical Ophthalmology

\section{Publish your work in this journal}

Clinical Ophthalmology is an international, peer-reviewed journal covering all subspecialties within ophthalmology. Key topics include: Optometry; Visual science; Pharmacology and drug therapy in eye diseases; Basic Sciences; Primary and Secondary eye care; Patient Safety and Quality of Care Improvements. This journal is indexed on PubMed

\section{Dovepress}

Central and CAS, and is the official journal of The Society of Clinical Ophthalmology (SCO). The manuscript management system is completely online and includes a very quick and fair peer-review system, which is all easy to use. Visit http://www.dovepress.com/ testimonials.php to read real quotes from published authors. 